\author{
Наталія Миколаївна Оніщенко, \\ завідувач відділом теорії держави і права \\ Інституту держави і права ім. В. М. Корещького НАН Украӥни, \\ доктор юридичних наук, професор, \\ академік НАПрН Украӥни, заслужений юрист Украӥни
}

\title{
ПРАВОВИЙ МОНІТОРИНГ: ВІД ТЕОРІЇ ДО ПРАКТИКИ
}

Постановка проблеми. Правовий моніторинг в сучасному науковому доробку є недостатньо вивченим та проаналізованим як з теоретичного, так і прагматичного форматів дослідження. Особливо актуальною в цьому контексті є засади та принципи нормопроектувальної діяльності.

Аналіз останніх досліджень та публікацій. Дана проблематика ще не стала предметом ретельного вивчення, переважна більшість вітчизняних та зарубіжних вчених зосереджувала свою увагу на окремих іï аспектах та напрямах: В. Нагребельний, Н. Оніщенко, І. Онищук, Ю. Шемшученко, I. Шутак, О. Ющик.

Мета статті - дослідити сутність, природу, доктринальну «наповненість» та прагматичну значущість категорії «правовий моніторинг»

Основні результати дослідження: У сучасному науковому доробку не поодинокі думки з приводу визначення природи правового моніторингу, зокрема проголошується, що він полягає у виявленні суперечностей, колізій, прогалин, у нормах чинного законодавства, результатом якого $є$ вироблення пропозицій щодо вдосконалення законів і підзаконних нормативно-правових актів [1, с. 140]. Втім дослідження цього явища у правовій площині, якщо і не $€$ поодинокими, проте на сьогодні не розкривають всієї палітри цієї категорії в доктрині і не вгамовують прагматичний запит практики.

Враховуючи наявну наукову базу, хотілося б поставити і відповісти на деякі питання, пов'язані 3 теоретичним та практичними осмисленням категорії «правовий моніторинг», зокрема: 1) чи слід акцентувати увагу на тому, що моніторинг є тільки «екскурсом по негативах» чи це і «експедиції в позитивні аналітичні напрацювання»; 2) чи є ідентичними терміни «моніторинг» і «аналіз», чи виступають вони синонімами в сучасному науковому обігу; 3) яке навантаження складають функції правової аналітики при проведенні правового моніторингу тощо.

Як нам видається, правовий моніторинг повинен спрямовуватися, в першу чергу, на пошук позитивної практики (позитивного досвіду) з метою отримання відповідних узагальнень, так, прикладом можуть слугувати теоретичні функції правової аналітики, що здебільшого обслуговують правовий моніторинг в різних сферах наукового знання.

1. Гносеологічна (пізнавальна) функція. Правова аналітика сприяє розширенню та поглибленню наукових знань про правовий розвиток України, розкриваючи загальні та специфічні риси, аналізуючи стабільні та тимчасові правові ситуації в різних державах, досліджуючи функціонування певних елементів правової системи в особливих національних, політичних і соціально-економічних умовах. Аналіз і оцінка загального і особливого у тих чи інших правових явищах дозволяє створювати відповідні типології та класифікації, спрогнозовані на майбутнє.

2. Еврестична функція. Правова аналітика забезпечує не лише механічне накопичення знань про різні правові явища та процеси, але й аналізує стійкі, повторювані зв'язки між ними, виявляє закономірності та тенденції виникнення, функціонування і розвитку різних правових явищ та окремих юридичних інститутів.

3. Прогностична функція. Дослідження закономірностей і пріоритетів розвитку правових феноменів сучасності та загальносвітових політичних, економічних та юридичних процесів (таких, наприклад, як глобалізація) дозволяє спрогнозувати подальший розвиток як окремих засобів правового регулювання, так і права загалом.

4. Критична функція. Правові дослідження дозволяють побачити недоліки та прорахунки розвитку власної правової системи та правових систем інших країн. Неупереджений аналіз іноземної юридичної практики сприяє також деідеологізації правових доктрин і теорій [2, с. 138].

Як бачимо, кожна з них відтворює, віддзеркалює мінімодель правового моніторингу, який спрямований саме на вивчення позитивного конструктивного досвіду в правовій площині. 
Наступним питанням, на якому нам би хотілося зосередитися, $є$ питання категоріально-понятійного гатунку. Наприклад: чи доцільно ототожнювати терміни «моніторинг» та «аналіз»? Отже, звернемося до словникового доробку. Спочатку до питання про словниковий доробок. Так, «моніторинг» (від англ. мonitoring ) - це постійний контроль за будь-яким процесом з метою виявити, чи відповідає він бажаному результату або початковим прогнозам [3, с. 465].

Також «моніторинг» визначається як постійне спостереження за якимось процесом, явищем 3 метою виявити його відповідність певним нормам, прогнозам, бажаному результату [4, с. 285]. Крім того, «моніторинг» характеризується - як безперервне стеження за яким-небудь процесом 3 метою виявлення його відповідності бажаному результату, а також прогнозування, запобігання критичним ситуаціям [5, с. 687].

Декілька словникових визначень стосовно терміна «аналіз». Аналіз характеризується як метод наукового дослідження, що полягає в умовному чи фактичному розкладенні цілого на складові частини [4, c. 23]. Також аналіз (від грец. analysis) - метод наукового дослідження, що полягає у розгляді окремих сторін, властивостей, компонентів чого-небудь [3, с. 28]. Аналіз, метод наукового дослідження предметів, явищ та ін. шляхом розкладу, розчленування їх у думці на складові частини [5, с. 27].

Таким чином, вищевикладене дає нам підстави для розмежування понять «моніторинг» i «аналіз», тобто розуміння того, що вони не є тотожні категорії. Обгрунтувати це можна наступним:

1) по-перше, моніторинг - це постійно триваючий процес;

2) по-друге, саме аналіз можливо і слід розглядати як складову моніторингу;

3) по-третє, якщо аналіз - це здебільшого метод дослідження, то моніторинг - засіб осягнення відповідної реальності.

3 огляду на зазначене правовий моніторинг можна визначити, як постійне вивчення певних правових явищ або правових процесів з метою надання відповідних доктринальних узагальнень, прогностичних висновків задля використання їх правореалізаційною практикою. Яскравою прикладною ілюстрацією до зазначеного може слугувати постійне вивчення нормопроектувальної діяльності [6, с. 15-22].

С зрозумілою теза, що якість нашого життя прямо залежить від якості законодавства. Доволі зрозумілими в такий спосіб $\epsilon$ вимоги до законодавства: в першу чергу, щоб це не був «холостий постріл», який залишається на папері або електронному носії. По-друге, законодавство повинно бути «фортецею», захисником від сваволі чиновника, провідником «у простір свободи, безпеки і правосуддя» [1]. По-третє, є цілком очевидні і встановлені критерії щодо якості нормативно-правового акта. Так, нормативно-правовий акт повинен відповідати реаліям життя, розвитку всієї правової системи, бути ресурсозабезпеченим, відповідним Конституції як Основному Закону держави тощо. Отже, нормотворчість на усіх рівнях від вищих органів державної влади (загальна нормотворчість), центральних органів виконавчої влади (відомча нормотворчість), місцевих органів виконавчої влади (місцева нормотворчість), до нормотворчості керівників підприємств, установ, організацій (локальна нормотворчість) повинна дієво забезпечувати права, свободи і законні інтереси людини.

Вже давно назріла теза про те, що законодавство потребує постійного оновлення та удосконалення, а процес нормопроектування повинен не тільки зазнати позитивних змін, але й, нарешті, продемонструвати ефективність та результативність.

Зрозуміло, що категорії «ефективність» та «результативність», коли мова іде про законодавчу базу, можуть розглядатися в контексті причинно-наслідкових зв'язків, де причиною виступає ефективність, а результатом авторитетність, оскільки кожне явище соціальної дійсності, що ефективно виконує свої функції, завжди поважається та поціновується у суспільстві. Після загальних зауважень, розуміючи необхідність нагального вирішення означених проблем, хотілося б зупинитися на ряді дисфункцій, прогалин, а іноді навіть аномалій, що існують у нормопроектувальній діяльності, а саме:

1) наявність великої кількості правових актів, що регулюють однотипні правові відносини;

2) дублювання нормативно-правових приписів у різних нормативно-правових актах, що знаходяться нерідко у ієрархічній послідовності;

3 ) декларування в нормативно-правових актах, прав і обов'язків (повноважень) без встановлення належних механізмів їх реалізації; 
4) зокрема, відсутність або неналежна якість наукових напрацювань щодо нормопроектувальної діяльності. Зокрема навіть короткий аналіз останніх публікацій вітчизняних вчених говорить про хаотичний, інколи епізодичний, і навіть, «куций» характер таких напрацювань;

5) ще одним недоліком у зазначеній сфері, зокрема хаотичності та невизначеності процедури нормопроектування, можна вважати те, що стадії нормопроектування характеризуються рисами самостійності та завершеності, що і обумовлює складний характер та зміст нормопроектувальної діяльності. Мова іде про відокремленість, непов'язаність стадій між собою;

6) також доречно, на наш погляд, привернути увагу представників доктрини та юридичної практики до необхідності вивчення нормотворчої діяльності та, відповідно, нормопроектування, залежно від типу правової системи. Зокрема, в останньому випадку мова може іти про так зване «бінарне» порівняння. Тобто, коли дві або більше країн досягли однакових результатів (в даному випадку у форматі нормопроектувальної діяльності), хоча розроблялися і впроваджувалися різні практики. Отже, заявлений перелік проблемних питань в нормопроектувальної діяльності є свідченням проведеного і такого, що проводиться правового моніторингу, який рельєфно демонструє поєднання теоретичного блоку (доктрини) і напрацювань практики в означеній площині, а також деталізує зарубіжний досвід щодо цього питання.

Саме правовий моніторинг - це категорія, що дає відповідь на питання, як врегульований законодавчий процес в різних країнах світу. Тобто, яким $\epsilon$ «начало начал» життя законодавчого акта. Правове регулювання законодавчого процесу у різних країнах характеризується певними особливостями, що зумовлено, насамперед, історичними умовами розвитку конкретної держави, структурою парламентів, певними традиціями та звичаями, специфікою конституційно-правового регулювання.

Для практики унормування законодавчого процесу властиві два підходи. Перший - класичний притаманний більшості держав, у парламентах яких законодавчий процес відбувається із застосуванням процедур трьох читань і лише в окремих, визначених випадках, допускається можливість прийняття законів за процедурами двох читань (Бельгія, Іспанія, Латвія, Німеччина, Словенія).

Інший підхід - новітній - полягає у прийнятті парламентами законодавчих актів в основному за процедурами двох читань (Болгарія, Данія, Литва, Португалія, Румунія, Словаччина). У таких країнах на конституційному рівні з метою запобігання «зведення» законодавчого процесу до процедури одного читання закріплюється мінімальний стандарт, що передбачає прийняття законів із застосуванням процедур не менше, як двох читань. Такий підхід дозволяє значно «розвантажити» роботу парламенту в пленарному режимі, оскільки «левову частку» роботи щодо опрацювання законопроектів та узгодження всіх пропозицій та поправок до них виконують парламентські комітети.

Друге читання проводиться у двох форматах. Перший або звичайний починається з доповіді голови профільного комітету про стан законопроекту після його доопрацювання у комітеті; у форматі загальних дебатів обговорюються пропозиції щодо внесення поправок; відбувається постатейне голосування по тексту законопроекту. Другий або спеціальний формат застосовується для обговорення законопроектів, пов'язаних з питаннями державних доходів, видатків і питань оподаткування та передбачає обов'язкове створення Комітету всієї Палати (Committee of the Whole House) із депутатів, які виявили бажання увійти до його складу. За рішенням Палати допускається застосування такого формату і для розгляду інших законопроектів у другому читанні.

У практиці унормування процедури реєстрації законопроектів у європейських парламентах можна визначити такі підходи. Формальний - суть його полягає у здійсненні реєстрації поданих суб'єктами права законодавчої ініціативи всіх без винятку законопроектів і тільки після цього парламент надає згоду на їх розгляд (Болгарія, Румунія, Чехія, Чорногорія). Неформальний базується на принципі попереднього вирішення відповідним уповноваженим органом парламенту (Бюро, Президія, Рада, парламентський комітет) питання про прийняття до розгляду законопроектів і тільки після цього здійснюється процедура їх реєстрації. Так, у Португалії дозвіл на реєстрацію законопроектів надається Головою Асамблеї на основі висновку Бюро Асамблеї (ст. 125 Правил процедур парламенту). В Угорщині законопроект може бути зареєстрований в парламенті за умови його підтримки відповідним профільним комітетом (ст. 98 Регламенту). В Естонії рішення про реєстрацію законопроекту ухвалюється Радою парламенту (ст. 93 Правил процедур Рийгікогу). 
Застосування неформального підходу оцінки законопроектів для цілей їх реєстрації значною мірою зменшить або навіть унеможливить внесення до парламенту невідповідних законопроектів, підвищить рівень відповідальності суб'єктів права законодавчої ініціативи та, безумовно, сприятиме посиленню ефективності діяльності парламенту.

Що стосується організації процедур розгляду законопроектів, доцільно звернутися до парламентського досвіду таких держав, як Греція, Італія, Іспанія, Польща, Чорногорія, де комітети мають досить широкі повноваження в законодавчому процесі [7, с. 23].

Ще один «практичний зріз» проблеми. Одним із нагальних та найбільш проблематичних питань справедливо називають проблему якості законопроектів, що, на думку дослідників, значною мірою залежить від всебічного їх опрацювання в комітетах [8, с. 11].

Вченими обгрунтовується доцільність запровадження процедури узгодження поправок до законопроектів 3 їх ініціаторами при підготовці законопроекту до розгляду за процедурою другого читання. Така процедура дозволить комітетам опрацювати всі запропоновані суб'єктами права законодавчої ініціативи поправки та дійти згоди щодо них, що певною мірою сприятиме оптимізації розгляду проектів законодавчих актів у другому читанні на пленарних засіданнях Верховної Ради України [9, с. 47].

Підвищення якості законопроектів, на думку окремих науковців, вбачається в обов'язковому нормативному закріпленні врахування експертних висновків щодо законопроектів при їх розгляді. При цьому зміст висновків повинен бути озвученим представником комітету під час виступу.

Згідно з попереднім контекстом заслуговує на особливу увагу і вивчення прикладів зарубіжного досвіду у сфері правового регулювання, нормотворчості і особливостей використання правил нормопроектувальної техніки, про що вже неодноразово писали вітчизняні вчені, застосовуючи метод порівняльного аналізу [10, с. 256-263].

Так, наприклад, у Бельгії в Інституті соціального права на вимогу Уряду розробляється нормопроектувальна система під назвою «SOLON» для визначення якості законодавства, яка включає в себе матеріальний критерій (зміст нормативно-правових актів) та формальний критерій (структуpa, спосіб оформлення тощо). Більше того, така ідея не є новою, аналогічні системи вже застосуваються в Королістві Нідерландів (LEPA, OBW) в Італійській Республіці (Lexidit, Lexeditior IRI_AI, Arianna, Norma). Правознавці зазначають, що існує навіть ціла наука «legimatics», яка займається вивченням та дослідженням можливостей комп'ютерної техніки у сфері нормопроектування.

Вчені-дослідники також зазначають, що нормотворчість у Королівстві Нідерландів привертає увагу існуванням та застосуванням алгоритмів створення правових норм, які перетворюють формули в юридичні норми, що значно спрощує та прискорює процес нормотворчості, але при цьому вимагає спеціальних математичних знань та знання інформатики. Цей досвід, як нам видається, має розглядатися у вітчизняних Наукових центрах та Вищих закладах освіти. Про це свідчать, зокрема, напрацювання ХНУРЕ (Харківській національний університет радіоелектроніки).

Крім того, цікавою ілюстративною прикладною базою можна вважати практику урегулювання цього питання у Республіці Казахстан, Азербайджанській Республіці та інших державах.

Окрема увага в цьому контексті може бути присвячена нормопроектувальній діяльності в Канаді, де така діяльність вважається «мистецтвом, а не буденною справою». Такою діяльністю займається близько 100 чоловік. Враховуючи досвід одного з нормопроектувальників - (Р. К. Бержерона), можна виокремити ряд правил нормопроектувльної діяльності:

1) фіксація ключового філософського положення про взаємовідповідність змісту та форми проекту;

2) автор правил нормопроектування пропонує враховувати часовий (темпоральний) чинник такої діяльності, вважаючи, що недостатній час може впливати на якість розробки і саму якість нормативно-правового акта;

3) Р. К. Бержерон звертає увагу на важливість професійного підходу до такої діяльності (фактор професіоналізації);

4) увага обов'язково повинна зосереджуватися на можливому негативному результаті нормопроектування (фактор негативізації нормопроектування). Тобто мова, з нашого погляду, йде про те, що сам нормативно-правовий акт не зможе не тільки сприяти кращому упорядкуванню праворегулюючих процесів, а навіть навпаки - може серйозно в подальшому вплинути на їх якість і дієвість; 
5) констатується, що правила нормопроектування не є і ніколи не будуть абсолютними (фактор деабсолютизації), оскільки не можуть охопити всю сукупність розробки і оформлення нормативних текстів;

6) обов'язково повинні враховуватися телеологічні домінанти нормопроектування (телеологічний фактор) [11, с. 24].

Також цікавий досвід запропонувало українському Уряду Міністерство Великої Британії з міжнародного розвитку (Центр Законодавчих студій сера Вільяма Дейла при Інституті поглиблених правних студій - Лондонський університет). Зокрема, мова йде про Проект підтримки нормопроектування, що включає наступні стадії:

1) створення українського стилю нормотворення, який зможе запобігти існуючим неузгодженостям у законодавстві, що спричинені роботою різних груп нормотворців та різними джерелами права;

2) зменшення потреби у поточних консультаціях з іноземними радниками, нормотворча техніка яких грунтується на правилах нормопроектування, притаманних юрисдикції інших країн;

3) надання допомоги українському Урядові у приведенні українського законодавства у відповідність із законодавством Європейського Союзу;

4) поглиблення існуючого розуміння принципів верховенства права, демократії, конституціоналізму, етики та справедливого правління та застосування їх у нормотворчому процесі;

5) боротьба з корупцією шляхом запобігання суперечностям та ліквідації прогалин у чинному законодавстві.

На наш погляд, до цих правил слід було б додати необхідність залучення як представників правової доктрини, так і представників юридичної практики. Певні спроби щодо цього неодноразово виникали в різних державних інституціях, зокрема, в Міністерстві юстиції України.

Висновки. Таким чином були проаналізовані деякі аспекти доктринального тлумачення категорії правовий «моніторинг», пов'язаність теорії і прагматики цього питання, акцентування уваги на необхідності вироблення як власного стилю науки спостереження, аналізу і прогностики (правовий моніторинг), так і врахування засад і підвалин вивчення зарубіжного досвіду проведення послідовних статей правового моніторингу задля покращення правореалізаційної практики.

\section{Список використаних джерел}

1. Онищук I. I. Правовий моніторинг із залученням громадських об'єднань та наукових інституцій // Вісник Національного університету «Львівська політехніка». Юридичні науки. - 2014. - № 801. - С. 139-146.

2. Оніщенко Н. Функції правової аналітики: теоретичні виміри, практичні засади // Visegrad journal on human rights. - 2017. - №№1/2. - С. 134-138.

3. Куньч 3. Й. Універсальний словник української мови : навч. посіб. - Тернопіль: Навчальна книга - Богдан, 2004. $-848 \mathrm{c}$.

4. Великий тлумачний словник. Сучасна українська мова / упоряд. А. П. Загнітко, І. А. Щукіна. - Донецьк : БАО, 2008. - 704 c.

5. Великий тлумачний словник сучасної української мови. (з дод. і допов.) / Уклад. і голов. ред. В. Т. Бусел. - К. : Ірпінь : ВТФ «ПЕРУН», 2005. - 1728 с.

6. Оніщеенко Н. М. Нормопроектувальна діяльність: вимоги теорії та практики // Право та юстиція. Науково-практичний юридичний журнал. - 2018. - № 4 (5). - С. 15-22.

7. Проблеми оптимізації інституційних засад законодавчої діяльності Верховної Ради України та їі комітетів. К. : Інститут законодавства Верховної Ради України, 2017. - 83 с.

8. Сас О. С. Організація роботи Верховної Ради України: питання теорії та практики : автореф. ... канд. юрид. наук : 12.00.02. - К., 2013. - 19 с.

9. Погорелова 3. О. Процедура розгляду законопроектів у Верховній Раді України: проблеми теорії та практики // Науковий вісник Ужгородського національного університету. Серія Право. - 2015. - Вип. 35. - Ч. 1., T. $1 .-$ C. $45-48$.

10. Петришина М. О., Мала Т. С. Нормопроектувальна техніка як засіб формування системи дієвого та ефективного законодавства в Україні: теоретико-правовий підхід // Актуальні питання публічного та приватного права. - 2014. - № 3. - С. 256-263.

11. Чорнолуцький Р. Правила нормопроектування Р. К. Бержерона та їх значення для становлення й розвитку національної системи нормопроектування в Україні // Jurnalul Juridic National: Teorie si Practica. - 2015. № 5/1. - C. 22-27. 


\section{References}

1. Onyshchuk I. I. Pravovyi monitorynh iz zaluchenniam hromadskykh obiednan ta naukovykh instytutsii // Visnyk Natsionalnoho universytetu «Lvivska politekhnika». Yurydychni nauky. - 2014. - № 801. - S. 139-146.

2. Onishchenko N. Funktsii pravovoi analityky: teoretychni vymiry, praktychni zasady // Visegrad journal on human rights. - 2017. - №№1/2. - C. 134-138.

3. Kunch Z. Y. Universalnyi slovnyk ukrainskoi movy: navchalnyi posibnyk. - Ternopil : Navchalna knyha - Bohdan, 2004. -848 s.

4. Velykyi tlumachnyi slovnyk. Suchasna ukrainska mova / uporiad. A. P. Zahnitko, I. A. Shchukina. - Donetsk : BAO, 2008. - $704 \mathrm{~s}$.

5. Velykyi tlumachnyi slovnyk suchasnoi ukrainskoi movy. (z dod. i dopov.) / Uklad. i holov. red. V. T. Busel. - K. : Irpin: VTF «PERUN», 2005. - $1728 \mathrm{~s}$.

6. Onishchenko N. M. Normoproektuvalna diialnist: vymohy teorii ta praktyky // Pravo ta yustytsiia. Naukovopraktychnyi yurydychnyi zhurnal. - 2018. - № 4 (5). - S. 15-22.

7. Problemy optymizatsii instytutsiinykh zasad zakonodavchoi diialnosti Verkhovnoi Rady Ukrainy ta yii komitetiv. K. : Instytut zakonodavstva Verkhovnoi Rady Ukrainy, 2017. - 83 s.

8. Sas O.S. Orhanizatsiia roboty Verkhovnoi Rady Ukrainy: pytannia teorii ta praktyky: avtoref. ... kand. yuryd. Nauk : 12.00.02. - K., 2013. - $19 \mathrm{~s}$.

9. Pohorelova Z. O. Protsedura rozghliadu zakonoproektiv u Verkhovnii Radi Ukrainy: problemy teorii ta praktyky // Naukovyi visnyk Uzhhorodskoho natsionalnoho universytetu. Seriia Pravo. - 2015. - Vyp. 35. - Ch. 1., T. 1. - S. 45-48.

10. Petryshyna M. O., Mala T. S. Normoproektuvalna tekhnika yak zasib formuvannia systemy diievoho ta efektyvnoho zakonodavstva v Ukraini: teoretyko-pravovyi pidkhid // Aktualni pytannia publichnoho ta pryvatnoho prava. 2014. - № 3. - S. 256-263

11. Chornolutskyi R. Pravyla normoproektuvannia R.K. Berzherona ta yikh znachennia dlia stanovlennia y rozvytku natsionalnoi systemy normoproektuvannia v Ukraini // Jurnalul Juridic National: Teorie si Practica. - 2015. № 5/1. - C. 22-27.

\section{Оніщенко Н. М. Правовий моніторинг: від теорії до практики}

Стаття спрямована на поєднання правової доктрини і юридичної практики у вивченні такої категорії, як правовий моніторинг. 3 іншого боку, надається характеристика цього феномену в контексті усунення недоліків і прогалин законодавчого поля, а також акцентується увага на важливості пошуку і поширення позитивної практики прагматичного аспекту правотворчого процесу.

Ключові слова: правовий моніторинг, правовий аналіз, правова аналітика, правова прогностика, нормопроектувальна діяльність.

\section{Onistchenko N. N. Legal monitoring: from theory to practice}

The article is aimed at combining legal doctrine and legal practice in the study of such a category as legal monitoring. On the other hand, the characteristic of this phenomenon is given in the context of the elimination of deficiencies and gaps in the legislative field, and also it is focused on the importance of finding and disseminating the positive practice of the pragmatic aspect of the law-making process.

Key words: legal monitoring, legal analysis, legal analytics, legal forecasting, normative design activity.

DOI: $10.33 .66 .3 / 2524-017 \mathrm{X}-2019-10-21-26$ 